\title{
Effects of temperature and salinity on inducing spawning in the eastern oyster (Crassostrea virginica) under laboratory conditions
}

\section{Efecto de la temperatura y la salinidad en la inducción al desove en el ostión (Crassostrea virginica) bajo condiciones de laboratorio}

\author{
Antonio Magaña-Carrasco ${ }^{1}$, Nancy Brito-Manzano ${ }^{1 *}$, Armando Gómez-Vázquez ${ }^{1}$, Aldenamar Cruz \\ Hernández ${ }^{1}$ \\ ${ }^{1}$ División Académica de Ciencias Agropecuarias, Universidad Juárez Autónoma de Tabasco. Cuerpo Académico Producción \\ Agropecuaria en el Trópico Húmedo. Km 25 carretera Villahermosa-Teapa, CP. 86280. Villahermosa, Tabasco, México \\ *Corresponding author: nancy.brito@ujat.mx
}

Scientific article received: October 15, 2016 accepted: October 02, 2017

\begin{abstract}
The effectiveness of two stimuli (thermal and salinity shock) in inducing spawning in the eastern oyster Crassostrea virginica was tested under laboratory conditions. Organisms were obtained in Machona Lagoon, located in Sánchez Magallanes, Tabasco. Temperatures used were 10, 15, 20, 25 and $30^{\circ} \mathrm{C}$ and the salinities were 10, 15, 20, 25 and $30 \mathrm{psu}$. The objective of this work was to determine the effects of salinity and thermal shock on spawning of $C$. virginica oyster. The best spawning results were obtained by using salinity shock, which induced spawning in $55 \%$ of the oysters tested, with the number of males that spawned being significantly higher than that of the females. Thermal shock was less effective with only $34 \%$ of organisms spawning and, unlike the salinity results, the number of females was higher than that of males. Temperatures of $30^{\circ} \mathrm{C}$ or greater had a negative effect on spawning and was similar at a salinity of $30 \mathrm{psu}$. The optimum time for spawning was between 11 and $15 \mathrm{~min}$ of exposure to salinity shock, whilst for thermal shock it was between 16 and 20 min.
\end{abstract}

Key words: Induction, spawning, oyster, Crassostrea virginica, Machona lagoon

RESUMEN. La efectividad del choque térmico y choque de salinidad sobre el desove del ostión americano Crassostrea virginica fue llevado a cabo bajo condiciones de laboratorio. Los organismos fueron obtenidos en la laguna Machona, Sánchez Magallanes, Tabasco. Las temperaturas empleadas fueron 10, 15, 20, 25 and $30{ }^{\circ} \mathrm{C}$ y las salinidades de 10 , 15, 20, 25 y 30 ups. Los mejores resultados en el desove se obtuvieron al emplear el choque de salinidad, el cual indujo el desove en $55 \%$ de los ostiones muestreados, siendo el número de machos que desovaron significativamente mayor que el de las hembras. El choque térmico fue menos efectivo con solo el $34 \%$ de organismos que desovaron y el número de hembras fue superior al de los machos. El tiempo óptimo para realizar el desove fue entre 11 y 15 min de exposición al choque de salinidad, mientras que para el choque térmico fue entre 16 y $20 \mathrm{~min}$.

Palabras clave: Inducción, desove, ostión, Crassostrea virginica, laguna Machona

\section{INTRODUCTION}

Oysters are broadcast spawners, releasing gametes into the water column. Spawning in the eastern oyster is regulated by seawater temperature and food availability (Kennedy et al. 1996). In the Gulf of Mexico, oysters exhibit multiple spawning per year. Gametogenic development occurs in the winter as well as spring. Spawning peaks in May but can continue until late August, though recycling of gonads with subsequent spawning can occur as late as October (Supan and Wilson 2001). Oysters are a keystone ecological species for the near shore marine environment as they improve water quality through filtering algae and pollutants out of the water column. The reefs created by oysters 
provide critical habitat for numerous species of fish and invertebrates. Oyster reefs also help to stabilize shorelines and reduce erosion (Piazza et al. 2005). Sustainable oyster populations in the wild provide jobs for commercial harvesters. In a controlled environment oyster aquaculture provides additional job opportunities.

The eastern oyster Crassostrea virginica (Gmelin, 1791) is found along the coast of the Gulf of Mexico, where water temperatures can vary greatly. In shallow waters, oysters can be frozen solid in winter and can thaw out and survive when water is available (Barber 1996). The oyster, in general, is an important commercial fishery in Mexico and particularly in Tabasco State. However, oyster production has declined in general throughout its distribution area due to disease, pollution and overexploitation (Barber 1996). This decline has led to research on the eastern oyster, especially in the areas of disease, pollution and reproduction (Buchanan et al. 1998). Exogenous factors potentially important in the initiation of spawning events in bivalves are salinity, lunar phase, water temperature, food availability, and presence of gametes in the water column (Barber 1996). An abrupt change in water temperature is considered the most important exogenous factor controlling spawning synchrony and is often associated with changing tides (Cáceres-Martinez and Figueras 1998).

Spawning induction is essential to bivalve hatchery production as it involves control of the timing of reproduction to make maximum fertilization. There are several ways to induce spawning in sexually mature bivalves, with the major methods being chemical stimulation, biological stimulation and physical shock. Parameters potentially triggering spawning including salinity, temperature, light, lunar phase, dissolved oxygen, mechanical shock, $\mathrm{pH}$, and chemical stimuli have been examined through correlation with field observation and laboratory experiments (Barber and Blake 1991). Bivalves are good aquaculture candidates as they are the greatest source of mollusk production and can be reared using simple technology
(Lucas and Southgate 2003). They reproduce by spawning, meaning the release of eggs and sperm into water which occurs when the reproductive organs are mature.

Salinity is one of the environmental factors influencing reproduction of estuarine and marine invertebrate. Long-range seasonal fluctuations in salinity are important to the synchronization of the gametogenic cycle, reproductive pattern and spawning induction (Ludi 2011). Temperature cycling involves placing broodstock bivalves in water at a certain temperature then slowly increasing the temperature of the water over a period of time. The temperate bivalve will spawn effectively by increasing the temperature. The initiation of spawning occurs with both declining and increasing temperature. However, salinity and temperature shock will give different spawning results for tropical and temperate bivalves (Ludi 2011).

In the life cycle of oyster, temperature is the most important factor that affects virtually every aspect of oyster biology including survival, feeding, growth, gonadal development, spawning, larval settlement, sex and disease outbreaks (Shumway 1996). The aim of this study was to evaluate the effect of two stimuli (salinity and temperature) on inducing spawning in the eastern oyster (Crassostrea virginica) under laboratory conditions, with the intention of exploring the possibility of developing reproduction techniques to produce oyster seeds under laboratory conditions that may help to recover overexploited fishing grounds if seed is restocked successfully at these sites in Tabasco, Mexico.

\section{MATERIALS AND METHODS}

Fort the experiment, 300 adult oysters (Crassostrea virginica) were collected from the Ma-

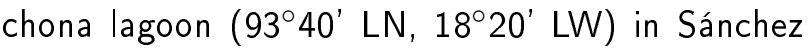
Magallanes, Tabasco, Mexico. Specimens were collected manually by removing the sediment up to $5 \mathrm{~cm}$ deep; oysters between 80 and $120 \mathrm{~mm}$ long (sexually mature specimens and commercially allowed size) were taken and transported in plastic containers filled with water from the capture 
site to avoid stress during transport to the División Académica de Ciencias Agropecuarias of the Universidad Juárez Autónoma de Tabasco, where particles were removed. The oysters were maintained under ambient light and temperature conditions before spawning. Ambient seawater temperatures ranged between $28.9^{\circ} \mathrm{C} \pm 1.9{ }^{\circ} \mathrm{C}$ and salinity from $33 \pm 2$ psu. In the laboratory, the oysters were placed in 150 $\mathrm{L}$ glass aquaria containing fresh water. These closed systems were aerated, maintaining the salinity at 33 psu and temperature at $29 \pm 1{ }^{\circ} \mathrm{C}$. The acclimatization period of the animals was $48 \mathrm{~h}$. On the day of spawning all oysters within the sample were randomly assigned to thermal or salinity shock. The oysters assigned to each treatment were placed individually in a $2 \mathrm{~L}$ container in a water bath, which maintained a standard $29 \pm 1^{\circ} \mathrm{C}$ in all treatments. All spawning stimuli were initiated by 7:00 h.

\section{Treatments}

Two different spawning induction methods were tested in the oyster; in the first method, the organisms were treated with the thermal shock treatment and in the second they were subjected to salinity shock. Adult oysters can survive in a wide range of salinities ( 0 to 42 ), but normally occur at salinities between 10 and 30 , while the temperature range is between 7 and $36^{\circ} \mathrm{C}$ (Hand and Stickle 1977).

\section{Temperature}

In this treatment a total of 150 oysters were subjected to about $30 \mathrm{~min}$ air-exposures before placement in the spawning containers $(2 \mathrm{~L}$ container filled with seawater at 33 psu and maintained at room temperature between $28 \pm 1{ }^{\circ} \mathrm{C}$ ). The receptacles were kept at five temperature levels $(10$, $15,20,25$ and $30^{\circ} \mathrm{C}$ ), each one with three replicates and 10 organisms. The procedure was started with the cold treatment. Temperature of the seawater was lowered to $10{ }^{\circ} \mathrm{C}$ with ice packs and maintained for $30 \mathrm{~min}$. After the cold treatment, a heater was used to raise the temperature of the seawater to 30 ${ }^{\circ} \mathrm{C}$ and was maintained for $30 \mathrm{~min}$ before another cooling process began. Oysters were checked for spawning at $5 \mathrm{~min}$ intervals for a further $30 \mathrm{~min}$.

\section{Salinity}

In this treatment a total of 150 oysters were subjected to about $30 \mathrm{~min}$ air-exposures before placement in the spawning containers $(2 \mathrm{~L}$ container filled with seawater at $33 \mathrm{psu}$ and maintained at room temperature between $28 \pm 1{ }^{\circ} \mathrm{C}$ ). The receptacles were kept at five salinity levels $(10,15$, 20,25 and 30 psu), each one with three replicates and 10 organisms. Oysters were transferred from 33 psu to containers with 10 psu and were kept there for $30 \mathrm{~min}$, then returned back to 33 psu water containers for the next half hour. Salinity was reduced by adding freshwater. Oysters were checked for spawning at $5 \mathrm{~min}$ intervals for a further $30 \mathrm{~min}$.

\section{Spawning}

All experiments (initiation of the stimuli, spawning, and fertilization) ran within a 07:00 $\mathrm{h}$ working day. The time from initiation of the spawning stimuli to commencement of spawning was recorded for each oyster that spawned. The number of females and males was recorded. The mean number of eggs per female was calculated after collecting all the eggs in a $20 \mathrm{~L}$ bucket, agitating and counting at least four sub samples taken with a $5 \mathrm{~mL}$ pipette. Sperm were not counted but only examined and classified as either motile or no motile.

\section{Fertilization and viability}

Within one to $2 \mathrm{~h}$ of spawning, the eggs from each treatment were fertilized with combined sperm from males within the same treatment. Two hours after fertilization when the four cell stage had been reached, three $5 \mathrm{~mL}$ samples were removed at random from each container and the numbers of divided and undivided eggs counted. About $10 \mathrm{~h}$ after fertilization, we removed three samples from each container and counted normal ciliated trochophore larvae, aberrant larvae, and non-hatched eggs.

\section{Statistical analysis}

Induced spawning success was evaluated through visual observation of the presence or ab- 
Table 1. Spawning success of the two spawning stimuli for Crassostrea virginica oysters. For each spawning test $S$ is the number of oysters spawning and $N$ is the number tested.

\begin{tabular}{ccccccccccccc}
\hline \multicolumn{1}{c}{ Thermal shock } & \multicolumn{1}{c}{ Females } & \multicolumn{3}{c}{ Salinity shock } \\
\multicolumn{1}{c}{} & Males & \multicolumn{1}{c}{ Males } & \multicolumn{3}{c}{ Females } \\
\hline Test & $\mathrm{S}$ & $:$ & $\mathrm{N}$ & $\mathrm{S}$ & $:$ & $\mathrm{N}$ & $\mathrm{S}$ & $:$ & $\mathrm{N}$ & $\mathrm{S}$ & $:$ & $\mathrm{N}$ \\
1 & 6 & $:$ & 17 & 3 & $:$ & 13 & 6 & $:$ & 15 & 9 & $:$ & 15 \\
2 & 4 & $:$ & 17 & 6 & $:$ & 13 & 9 & $:$ & 16 & 5 & $:$ & 14 \\
3 & 6 & $:$ & 15 & 13 & $:$ & 15 & 9 & $:$ & 15 & 10 & $:$ & 15 \\
4 & 12 & $:$ & 14 & 7 & $:$ & 16 & 15 & $:$ & 15 & 5 & $:$ & 15 \\
5 & 6 & $:$ & 16 & 6 & $:$ & 14 & 8 & $:$ & 16 & 6 & $:$ & 14 \\
Total & 34 & $:$ & 79 & 35 & $:$ & 71 & 47 & $:$ & 77 & 35 & $:$ & 73 \\
& & $43 \%$ & & & $49 \%$ & & & $61 \%$ & & & $48 \%$ & \\
\hline
\end{tabular}

Table 2. Average numbers of eggs produced by oyster females induced to spawn by Salinity shock and the percentages of eggs that were well formed, fertilized and hatched.

\begin{tabular}{ccccc}
\hline \multirow{2}{*}{ Test } & Average number of eggs & \multicolumn{3}{c}{ Percentage of eggs } \\
& produced per female spawning & $\begin{array}{c}\text { Good } \\
(0 \mathrm{~h})\end{array}$ & $\begin{array}{c}\text { Fertilized } \\
(\text { at 2 h })\end{array}$ & $\begin{array}{c}\text { Hatched } \\
\text { (at 20 h) }\end{array}$ \\
\hline 1 & 800000 & 99.1 & 93.2 & 87.8 \\
2 & 1350000 & 99.5 & 93.7 & 89.3 \\
3 & 1125000 & 99.3 & 95.6 & 93.2 \\
4 & 810000 & 98.9 & 95.3 & 92.6 \\
5 & 1200000 & 99.4 & 95.5 & 93.8 \\
Average for all spawning & 1057000 & 99.2 & 94.6 & 91.3 \\
\hline
\end{tabular}

sence of gametes in each container. The response time to first spawning was measured as the elapsed time from the start of each treatment. If spawning occurred, water samples were collected to determine the number of eggs and the amount of fertilized eggs. Counts were submitted to the Levene test to verify homogeneity of variance; normality was verified graphically. Response times were transformed to $1 / x$ to comply with normality and equalvariance assumptions. The comparison of the means was carried out using the t-test through permutation at $5 \%$ probability.

\section{RESULTS}

Both methods induced spawning during every test (Table 1); however, the best method was salinity shock with $61 \%$ and $48 \%$ of males and females spawned respectively, whilst only $43 \%$ of males and $49 \%$ of females spawned with thermal shock.

Of all females, $73 \%$ spawned, producing an average of one million eggs per female spawning (Table 2). On average, males spawned between 16 to $20 \mathrm{~min}$ after the induction of the stimu- lus. Females took significantly less time to initiate spawning ( $p<0.05$ ), averaging $9 \mathrm{~min}$. Both techniques did not induce any organism to spawn between 0 to $5 \mathrm{~min}$ of the stimulus (Figure 1 ).

All spawning produced viable gametes and larvae were reared until trochophore stage. Females spawned a high proportion of well rounded eggs (mean of 99\%) and fertilization rates were $94.6 \%$. The viability of the fertilized eggs was also high: $91 \%$ hatched as normal trochophore larvae ( $86 \%$ of the total eggs spawned).

With salinity shock $61 \%$ single males produced copious quantities of sperm which appeared normal and motile. Thermal shock technique only induced $49 \%$ females to spawn. Table 3 shows mean developmental time for all observed stages. Fertilization was recognized by the appearance of a thick fertilization membrane at 5 min. After 35 min, a polar body appeared as a protuberance at the egg animal pole. The first cleavage occurred $1.01 \mathrm{~h}$ after fertilization. The second and third cleavages occurred 1.17 and $1.29 \mathrm{~h}$ after fertilization, respectively. The fourth cleavage occurred $1.58 \mathrm{~h}$ after fertilization. Two to $5 \mathrm{~h}$ after fertilization, most embryos were in blastula and gastrula or mobile blas- 


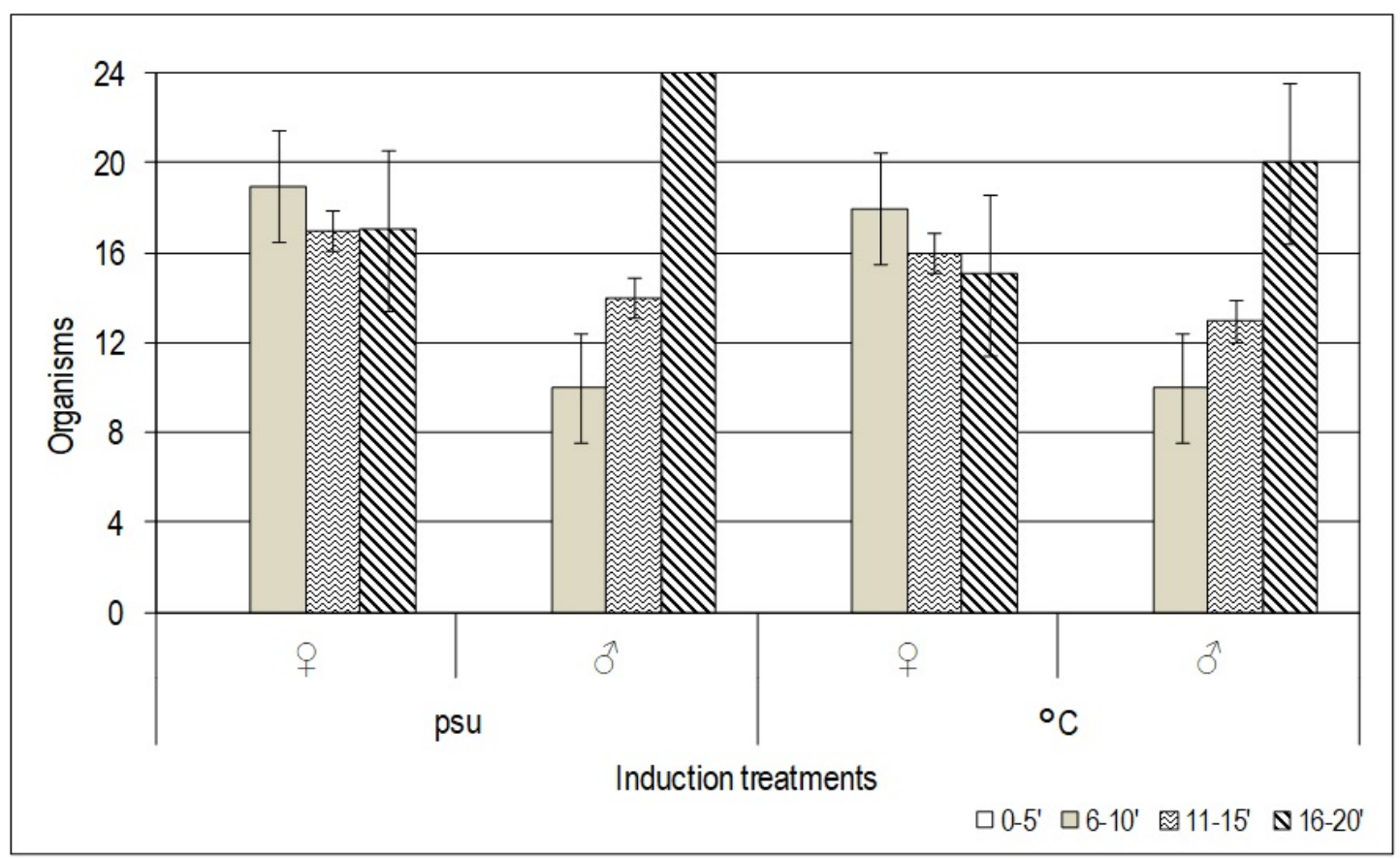

Figure 1. Average time to the initiation of spawning for males and females of the oyster Crassostrea virginica, for each one of the techniques.

tula stages, respectively. Trochophore larvae were observed approximately $10 \mathrm{~h}$ after fertilization (Table 3). Metamorphosis was numerically not successful under our laboratory conditions; we believe that bacterial contamination and subsequent mortalities were important factors constraining the final phase of the larval cycle.

Table 3. Timing of the early embryonic development of Crassostrea virginica under laboratory conditions.

\begin{tabular}{lc}
\hline Stage & Time after fertilization \\
\hline Polar body & $35.6 \mathrm{~min}$ \\
Cleavage first & $1.01 \mathrm{~h}$ \\
Cleavage second & $1.17 \mathrm{~h}$ \\
Cleavage third & $1.29 \mathrm{~h}$ \\
Cleavage fourth & $1.58 \mathrm{~h}$ \\
Blastula & $2.53 \mathrm{~h}$ \\
Gastrula or blastula mobile & $4.87 \mathrm{~h}$ \\
Trochophore & $9.95 \mathrm{~h}$ \\
\hline
\end{tabular}

\section{DISCUSSION}

Through this study, the induced spawning procedure under laboratory conditions for oyster $C$. virginica has been determinate; it makes use of only basic tools and equipment and requires no chemicals. Various induced spawning methods have been used on different bivalve species in order to produce seeds in a hatchery. Induced spawning, larval rearing and spat production of several mussel species, such as Perna viridis (Laxmilatha et al. 2011), Modiolus capax (Farfán et al. 2007) and Mytilus edulis (Galley et al. 2010) have been successfully carried out in laboratories and hatcheries; however, little attention has been paid to the production of oyster spat in large-scale hatcheries and the oyster industry still relies on the supply of seed from the wild (Alfaro et al. 2010; Laxmilatha et al. 2011; Wong and Arshad, 2013).

Under natural conditions, oyster spawning is generally believed to occur when water temperature increases above $20{ }^{\circ} \mathrm{C}$; moreover, they can spawn within a wide range of salinities ranging from 0 for short periods of time to 32-35 (full strength seawater). However, the optimal salinity for egg development ranges from 5-35 with optimal egg development at 10-23 (Hand and Stickle 
1977). Several species of Crassostrea have shown similar gametogenic cycles linked to varying seasonal coastal water temperatures. Paniagua-Cháves and Acosta-Ruíz (1995), who worked with C. gigas in Mina Vieja, Mexico, and Brousseau (1995), who worked with C. virginica in Bridgeport, CT, observed gonadal maturity of wild populations at warmer water temperatures, $20-23{ }^{\circ} \mathrm{C}$ and $20-30$ ${ }^{\circ} \mathrm{C}$, respectively. The oysters in this experiment were collected from the wild and stimulated within $48 \mathrm{~h}$ of collection; despite not observing gonadal maturity at first glance, the organisms spawned at warmer water temperatures, $20-30{ }^{\circ} \mathrm{C}$, similar to the level reported for the same species in Bridgeport, CT. Increasing water temperature to promote spawning has also been reported for other bivalves (De la Roche et al. 2002, Pronker et al. 2008, Matias et al. 2009). We cannot infer from our study whether a resting phase is required by $C$. virginica to mature successfully when conditioned at warm temperatures, such as those tested in our study. However, it is clear that more studies addressing the annual reproductive cycle of $C$. virginica throughout its geographical range of distribution are required to fully understand the role of environmental factors in their reproductive physiology. Nevertheless, most studies reviewed suggest that temperature constitutes a key environmental factor that regulates gametogenesis in $C$. virginica, triggering gonadal development at temperatures warmer than $28{ }^{\circ} \mathrm{C}$. Salinity changes have been reported to induce spawning in tropical oysters (Southgate and Lee 1998). It has been suggested that salinity-induced spawning may affect larval survival (Southgate and Lee 1998).

Development of embryos occurred only in conditions close to those at which spawning was conducted $\left(28^{\circ} \mathrm{C}\right)$. Similar observations have been made in temperature-salinity experiments with embryos of Mercernaria mercenaria (L.), C. virginica (Gmelin) (Davis and Calabrese 1964), Rangia cuneata (Gray) (Cain 1975) and Argopecten irradians irradians (Lamarck) (Tettelbach and Rhodes 1988).

According to Stephen and Sheety (1981), spawning was successfully induced in four bivalves
(Saccostrea cuccullata, S. commercialis, P. viridis and $P$. indica) by subjecting them to rapid salinity changes. Bivalve was maintaining at 34 psu for two month before decreasing the salinity at 26 psu. The results indicated that Crassostrea virginica has $50 \%$ salinity tolerance from 10 to 30 psu. It seems that suddenly increasing or decreasing salinity shock will be effective in inducing spawning of bivalves. In this work the salinity showed more influence on inducing spawning than temperature. In this sense, Ludi (2011) found that induction by thermal shock has a little success in Amusium pleuronectes when subjected to a temperature $10^{\circ} \mathrm{C}$ higher than the ambient temperature of $27^{\circ} \mathrm{C}$. Spawning in scallop Pecten alba was associated with increasing water temperature, while scallop Argopecten gibbus spawned by decreasing the water temperature. It has been argued that temperature and primary productivity are the most important exogenous factors regulating and synchronizing the reproduction cycle of bivalve species (Barber and Blake 2006).

\section{CONCLUSIONS}

The results of this study indicate that salinity shock was more effective than thermal shock in inducing spawning in C. virginica. However, given that this species is distributed throughout an extensive range of habitats, specific studies should be conducted to understand the effect of environmental variables on the development of larval stages. Moreover, further research is needed to optimize the production of $C$. virginica larvae under laboratory conditions and to develop optimal reproductive conditioning techniques in Tabasco, Mexico.

\section{ACKNOWLEDGEMENTS}

This study was supported by Fundación Produce Tabasco, A.C., CONAPESCA and SEDAFOP, a Tabasco State government body. Additional assistance was provided by the Universidad Juárez Autónoma de Tabasco. We acknowledge Gemma Franklin (a native English speaker) for her English review of this manuscript. 


\section{LITERATURE CITED}

Alfaro AC, McArdle B, Jeff AG (2010) Temporal patterns of arrival of beachcast green-lipped mussel (Perna canaliculus) spat harvested for aquaculture in New Zealand and its relationship with hydrodynamic and meteorological conditions. Aquaculture 302: 208-218.

Barber BJ (1996) Gametogenesis of eastern oysters, Crassostrea virginica (Gmelin 1791), and Pacific oyster, Crassostrea gigas (Thunberg 1793) in disease-endemic lower Chesapeake Bay. Journal of Shellfish Research 15: 285-290.

Barber BJ, Blake NJ (1991) Reproduction. In: Shumway SE, Parsons GJ (eds). Scallops: Biology, Ecology and Aquaculture. Elsevier, Amsterdam. pp: 394-407.

Barber BJ, Blake NJ (2006) Reproductive physiology. In: Shumway SE, Parsons GJ (eds) Scallops: Biology, Ecology and Aquaculture. Elsevier. Amsterdam. pp: 357-416.

Brousseau D (1995) Gametogenesis and spawning in intertidal oysters (Crassostrea virginica) from western Long Island Sound. Journal of Shellfish Research 14: 483-487.

Buchanan JT, Roppolo GS, Supan JE, Tiersch TE (1998) Conditioning of eastern oysters in a closed, recirculating system. Journal of Shellfish Research 4: 1183-1189.

Cáceres-Martinez J, Figueras A (1998) Long-term survey on wild and cultured mussels (Mytilus galloprovincialis LMK) reproductive cycles in the Ria de Vigo. (NW Spain). Aquaculture 162: 141-156.

Cain TH (1975) Reproduction and recruitment of the brackish water clam Rangia cuneata in the James River, Virginia. Fishery Bulletin 73: 412-430.

Davis HC, Calabrese A (1964) Combined effects of temperature and salinity on development of eggs and growth of larvae of M. mercenaria and C. virginica. U.S. Fish Wildl. Serv. Fishery Bulletin 63: 643-655.

De la Roche JP, Marín B, Freites L, Vélez A (2002) Embryonic development and larval and post-larval growth of the tropical scallop Nodipecten (= Lyropecten) nodosus (L. 1758) (Mollusca: Pectinidae). Aquaculture Research 33: 819-827.

Farfan C, Mungaray MR, Serrano-Guzmán SJ (2007) Seed production and growth of Modiolus capax conrad (Bivalvia: Mytilidae) in laboratory conditions. Journal of Shellfish Research 26: 1075-1080.

Galley TH, Batista FM, Braithwaite R, King J, Beaumont AR (2010) Optimisation of larval culture of the mussel Mytilus edulis (L.). Aquaculture International 18:315-325.

Hand SC, Stickle WB (1977) Effects of tidal fluctuations of salinity on pericardial fluid composition of the American oyster, Crassostrea virginica. Marine Biology 42: 259-272.

Kennedy VS, Newell IER, Eble AF (1996) The eastern oyster Crassostrea virginica. College, Park, MD. University of Maryland Sea Grant, Florida. Technical report. 53p.

Laxmilatha P, Rao GS, Patnaik P, Nageshwara P, Prasad Rao T, Dash B (2011) Potential for the hatchery production of spat of the green mussel Perna viridis Linnaeus (1758). Aquaculture 312: 88-94.

Ludi PA (2011) Review: Spawning Induction in Bivalve. Jurnal Penelitian Sains 14: 33-36.

Lucas JS, Southgate PC. 2003. Aquaculture farming aquatic animals and plants. Blackwell Publishing. Oxford. $12 p$

Matias D, Joaquim S, Leitão A, Massapina C (2009) Effect of geographic origin, temperature and timing of broodstock collection on conditioning, spawning success and larval viability of Ruditapes decussates (Linné 1758). Aquaculture International 17: 257-271. 
Paniagua-Cháves C, Acosta-Ruiz A (1995) Desarrollo gonadal de Crassostrea gigas en Bahía San Quintín, Baja California, México. Ciencias Marinas 20: 225-242.

Piazza BP, Banks PD, La Peyre MK (2005) The potential for created oyster shell reefs as a sustainable shoreline protection strategy in Louisiana. Restoration Ecology 13: 499-506.

Pronker AE, Nevejan NM, Peene F, Geijsen P, Sorgeloos P (2008) Hatchery broodstock conditioning of the blue mussel Mytilus edulis (Linnaeus 1758): part I. Impact of different micro-algae mixtures on broodstock performance. Aquaculture International 16: 297-307.

Southgate PC, Lee PS (1998) Hatchery rearing of the tropical blacklip oyster Saccostrea echinata (Quoy and Gaimard). Aquaculture 169: 275-281

Stephen D, Shetty HPC (1981) Induction of spawning in four species of bivalves of the Indian coastal waters. Aquaculture 25: 153-159.

Supan JE, Wilson CE (2001) Analysis of gonadal cycling by oyster broodstock, Crassostrea virginica (Gmelin) in Louisiana. Journal of Shellfish Research 1: 215-220.

Tettelbach ST, Rhodes EW (1988) Combined effects of temperature and salinity on embryos and larvae of the northern bay scallop Argopecten irradians irradians. Marine Biology 63: 249-256.

Wong NL, Arshad A (2013) Induced spawning and early development of Modiolus philippinarum (Hanley 1843) (Bivalvia: Mytilidae). Asian Journal of Animal and Veterinary Advances 8:100-107. 